State of the Art Review: Risk Factors for TB in Low Burden Countries

\title{
Active case finding and treatment adherence in risk groups in the tuberculosis pre-elimination era
}

Rishi K. Gupta ${ }^{1}$, Marc Lipman ${ }^{2,3}$, Alistair Story ${ }^{4}$, Andrew Hayward ${ }^{5}$, Gerard de Vries ${ }^{6,7}$, Rob van Hest $^{8,9}$, Connie Erkens ${ }^{6}$, Molebogeng X. Rangaka ${ }^{1}$, Ibrahim Abubakar ${ }^{1}$

1. Institute for Global Health, University College London, London, UK

2. UCL-TB and UCL Respiratory, University College London, London, UK

3. Royal Free London NHS Foundation Trust, London, UK

4. Find \& Treat, University College London Hospitals, London, UK

5. Institute of Epidemiology and Health Care, University College London, London, UK

6. KNCV Tuberculosis Foundation, The Hague, The Netherlands

7. The Hague and National Institute for Public Health and the Environment, Bilthoven, The Netherlands

8. Regional Public Health Service Groningen, Department of Tuberculosis Control, The Netherlands

9. University Medical Centre Groningen, Department of Pulmonary Diseases and Tuberculosis, Groningen, The Netherlands

Running Title: Active case finding and treatment adherence in risk groups

\section{Corresponding Author:}

Dr Rishi K. Gupta

Institute for Global Health,

$4^{\text {th }}$ Floor Mortimer Market Centre,

University College London,

WC1E 6JB

r.gupta@ucl.ac.uk

Word Count: Abstract $=248 ;$ Text $=3,990 ;$ Tables $=3 ;$ Figures $=1 ;$ Boxes $=2 ;$ References $=91$

Key Words: homeless; prisoners; high-risk drug users; vulnerable populations; screening; observed therapy 


\begin{abstract}
Vulnerable populations (including homeless persons, high-risk drug and alcohol users, prisoners, and other marginalized populations) contribute a disproportionate burden of tuberculosis (TB) cases in low-incidence settings. Drivers for this disease burden include increased risk of both TB transmission in congregate settings, and progression from infection to active disease. Late diagnosis and poor treatment completion further propagate the epidemic and fuel the acquisition of drug-resistance. These groups are therefore a major priority for TB control programmes in low-incidence settings. Targeted strategies include active case finding initiatives and interventions to improve treatment completion, and should be tailored to local populations. Active case finding most commonly deploys mobile x-ray unit screening, which allows sensitive, high throughput screening with immediate availability of results. Such initiatives have been found to be effective and cost-effective, and associated with reductions in proxy measures of transmission among hard-to-reach groups. The addition of point-of-care molecular diagnostics and automated x-ray readers may further streamline the screening pathway. There is little existing evidence to support interventions to improve adherence among these risk groups. Such approaches include enhanced case-management and directly-observed therapy, while video-observed therapy (currently under evaluation) appears to be a promising tool for the future. Integrating outreach services to include both case-detection and case-management interventions that share a resource infrastructure may allow cost-effectiveness to be maximised. Integrating screening and treatment for other diseases prevalent among targeted risk groups into TB outreach interventions may improve cost-effectiveness further. This article reviews the existing literature, and highlights priorities for further research.
\end{abstract}




\section{Introduction}

The World Health Organization (WHO) End TB strategy, aiming to reduce tuberculosis (TB) incidence and TB mortality by $90 \%$ and $95 \%$ respectively by 2035 , poses major challenges to TB control programmes in low TB incidence settings (defined as countries with an annual incidence of $\leq 10 / 100,000)^{1}$. The goal in these settings is to achieve pre-elimination (defined as an annual incidence of $<1 / 100,000$ ) and to move towards elimination by $2035^{2}$. In order to achieve this, the setting-specific challenges in TB control in these low-incidence countries must be addressed. This requires special attention to specific populations at highest risk of TB disease, among whom much of the disease burden is now concentrated ${ }^{2-4}$.

Vulnerable populations (including homeless persons, high-risk drug users, prisoners, asylum seekers, and other marginalized populations) contribute a disproportionate number of TB cases in lowincidence settings ${ }^{1-3}$. Previous studies have attempted to quantify these disease burdens. Studies of homeless people have shown that the prevalence of active TB is heterogeneous, ranging from 200$7,700 / 100,000$, with increased prevalence found in studies using chest radiography-based diagnosis, and in settings with higher general population TB prevalence ${ }^{5}$. Using systematic review and metaanalysis, Dolan et al. estimated that approximately 2,800/100,000 of incarcerated individuals globally have active $\mathrm{TB}^{6}$. Among high-risk drug users in London, UK, the prevalence of TB was estimated at $354 / 100,000$, with a high proportion of cases being sputum smear-positive ${ }^{7}$. Alcohol-dependence is also associated with increased TB risk, estimated as a pooled relative risk of 2.94 in a systematic review and meta-analysis ${ }^{8,9}$.

Multiple drivers contribute to the elevated incidence of TB among these groups. Firstly, individuals in these groups are often at higher risk of TB exposure due to socio-environmental conditions that predispose to increased TB transmission, including in congregate settings such as homeless shelters and prisons ${ }^{10-12}$. Secondly, they are often at greater risk of progression from infection to TB disease. This may be due to several, synergistic factors, including poor nutrition ${ }^{13}$, co-infection with $\mathrm{HIV}^{14}$, alcohol misuse ${ }^{8}$ or high-risk drug use $\mathrm{e}^{15,16}$. These factors are propagated by TB cases within these groups often being diagnosed late (due to a lack of access to healthcare and late recognition of symptoms), and frequently receiving suboptimal therapy (due to the challenges of linkage and retention in care, and ensuring sustained adherence to treatment ${ }^{15}$. This, in turn, increases the potential duration of their infective period, thereby increasing the risks of onward TB transmission, and the acquisition of drug-resistance. Further, when TB cases are eventually diagnosed, conventional contact investigations are often inadequate due to the difficulty of identifying contacts reliably ${ }^{17}$. 
Recent global and European guidance highlights a clear need to strengthen TB control efforts among vulnerable groups in low-incidence settings ${ }^{1,3}$. Approaches addressing this may include active case finding initiatives, in order to promote early case-detection of TB disease, along with interventions that improve linkage and retention in TB care, to increase treatment completion. This narrative review will discuss active case finding and adherence interventions when targeting homeless persons, highrisk drug users, prisoners, and other marginalised populations in low-incidence settings. Other important risk-groups include recent migrants and people living with HIV; these are beyond the scope of this review, as they are included in other articles in this series ${ }^{14,18}$. A literature search was conducted to support this review (Box 1). Definitions of key terms used in this review, including active case finding and adherence, are included in Box 2.

\section{Active case finding in risk groups in the TB pre-elimination era}

\section{Screening tools and algorithms}

Active case finding involves the systematic identification of individuals with suspected active TB, in a pre-determined target group ${ }^{19}$. This requires the implementation of a pre-defined screening algorithm and may utilise tools including symptom questionnaires, chest radiographs (either mobile or off-site), or sputum diagnostics. Desirable qualities of a screening algorithm include high sensitivity, low cost, high throughput and rapid turnaround time. Table 1 summarises the sensitivity of available screening tools.

Symptom screening is generally thought to be of little value in risk groups in low-incidence settings due to limitations of poor sensitivity and specificity (particularly among populations with high prevalence of smoking, alcohol and drug use $)^{19,20}$. Data evaluating the use of symptom screening as the sole initial screening tool are therefore scarce, though it may be used in combination with other methods.

Chest radiography, previously deployed for mass radiography screening for $\mathrm{TB}^{21}$, has re-emerged as a valuable initial screening tool among risk groups in recent years due to a number of strengths. These include:- the development of mobile digital radiography; relatively low cost; high throughput; high diagnostic accuracy; and immediate availability of results ${ }^{22-25}$. Chest radiography, regardless of symptoms, has therefore been the initial screening test of choice in the majority of recent studies evaluating active case finding interventions among risk groups in low-incidence settings. It should be noted, however, that sensitivity is reduced in populations with a high prevalence of advanced HIV infection - which may be relevant to some high-risk groups (e.g. injecting drug users) targeted by 
interventions ${ }^{26}$. An example screening algorithm using a mobile $\mathrm{x}$-ray unit (MXU) is demonstrated in Figure 1.

Sputum diagnostic tools for TB include smear microscopy, culture and molecular tests. Smear microscopy, while cheap and relatively fast to perform, is limited by poor sensitivity so is of little value as a screening tool ${ }^{19}$. Mycobacterial culture remains the gold-standard for the microbiological diagnosis of TB. It has generally been thought to have a limited role in active case finding among hard-to-reach groups in low-incidence settings due to the limitations of being dependent upon individuals' ability to produce good quality sputum samples, and slow turnaround time (up to 6 weeks) - which raises the challenge of locating positive cases after their initial screening ${ }^{23}$. However, a recent study in Copenhagen, Denmark, has shown that it may be of value in some settings ${ }^{27}$. Current molecular diagnostic tests, such as the Xpert MTB/RIF assay (Cepheid, Sunnyvale, USA), are relatively sensitive, very specific and allow fast turnaround time $(<2 \text { hours })^{28}$. They also have the potential for implementation at the point-of-care, though high cost and limited throughput mean that they are not currently viable as an initial screening tool, but may be reserved as diagnostic tools for individuals identified as high-risk of TB from the initial stage of the screening algorithm. Novel pointof-care molecular diagnostics are in the pipeline, and offer the hope of implementation as first-line screening tests in the future ${ }^{29}$.

Another approach to active case finding among risk groups is the combination of a symptom screen and tuberculin skin-test (TST) as the initial screening tools, with chest radiography performed if either is positive ${ }^{30-33}$. While both methods have low sensitivity for active TB when used in isolation, this approach relies on a high negative predictive value when both are negative. However, drawbacks include low specificity, and the requirement for at least two visits to read results. Interferon-gamma release assays (IGRA) also continue to be evaluated as tests for active $\mathrm{TB}^{34}$, but are also impaired by limited sensitivity, high cost and the requirement of a specialist laboratory ${ }^{35}$. Both TST and IGRA are therefore more commonly applied when the primary goal is screening for LTBI rather than TB disease.

Table 2 summarises published studies evaluating active case finding interventions among high-risk groups in low-incidence settings.

\section{Mobile x-ray unit screening}

Multiple studies have evaluated MXU screening approaches. The Find \& Treat service in London, UK, involves a MXU screening intervention, targeting a mixed hard-to-reach population that includes homeless persons, prisoners, high-risk drug users and asylum seekers ${ }^{36-38}$. The service was initiated 
after previous UK studies demonstrated the potential utility of active case finding using MXUs among these risk groups in UK cities ${ }^{39-43}$. The service has been evaluated in a number of studies. Story et al. linked individuals screened by the service to the national electronic surveillance system and demonstrated that the MXU diagnosed active TB with a sensitivity of $81.8 \%$ and specificity of $99.2 \%{ }^{36}$. This study also found that cases identified by the MXU were less likely to be smear-positive than matched, passively-diagnosed controls, thereby implying that the intervention may be effective in diagnosing active TB cases earlier, and suggesting a potential impact of earlier diagnosis on reducing risk of onward transmission ${ }^{36}$. Jit et al. conducted a cost-effectiveness evaluation of the intervention. Case-detection by the service was found to be cost-effective ( $£ 18,000$ - $£ 26,000$ / QALY gained $)^{38}$. Further, $35.4 \%$ of cases diagnosed by the service were asymptomatic, while $22.9 \%$ had been symptomatic for $>131$ days, suggesting that these individuals were unlikely to be diagnosed without the intervention ${ }^{38}$.

Mobile x-ray unit screening targeting homeless people across 28 shelters in Paris over a 14-year period found 179 TB cases (from an estimated 22,000 screened), and was associated with a reduction in the proportion of cases that were clustered over time, using restriction fragment length polymorphisms (RFLP), as a proxy measure of recent transmission ${ }^{44}$. De Vries et al. evaluated a similar intervention, targeting homeless people and high-risk drug users, in Rotterdam, The Netherlands. Over a 4-year period, 28 active TB cases were diagnosed by the intervention (prevalence 327/100,000); the authors also reported a reduction in RFLP-clustering over a time, suggesting a decline in recent transmission ${ }^{45}$. Implementation of the intervention as part of a wider comprehensive social rehabilitation programme for homeless people and drug users was associated with a marked reduction in TB incidence among these risk groups in Rotterdam over time. This resulted in a subsequent reduction in efficiency and yield of the intervention, which was therefore deemed no longer necessary and withdrawn at the end of $2014^{46}$.

In a systematic review and meta-analysis of 16 studies from Western Europe, Japan, USA and Australia, the pooled prevalence of active TB from chest radiography screening of homeless people was estimated as 931/100,000 (range $434-3,015)^{22}$.

\section{Other active case finding approaches}

Jensen et al. implemented spot sputum screening (using microscopy and culture) among a mixed hard-to-reach population in Copenhagen in Denmark ${ }^{27}$. They demonstrated an initial TB prevalence of $2,233 / 100,000$. Only $7 / 36(19.4 \%)$ of cases were sputum smear-positive, and only $83.3 \%$ had chest radiographic changes suggestive of $\mathrm{TB}$, suggesting that the remaining $17 \%$ may not have been diagnosed by an MXU intervention. While the median time to treatment was 32 days, it is 
encouraging that all cases diagnosed started TB therapy, of whom $83 \%$ completed. This study demonstrates that spot sputum screening may be feasible, particularly in settings where MXUs are not available, though further data are clearly required as locating individuals with positive culture results days or weeks after screening may yet prove to be challenging in practice.

Active referral to TB services for screening is another intervention that has been evaluated in European studies among drug users, homeless persons and migrants, finding a TB prevalence of 300$1,217 / 100,000$ among those screened ${ }^{47,48}$. Other studies from the USA using a symptom screen and TST as the initial screening test, with further evaluation including chest radiograph performed only if positive, have demonstrated a TB prevalence ranging from 0-1,217/100,000 among homeless people ${ }^{30-33}$. Two of these studies reported a reduction in TB incidence in US cities over the duration of the intervention, though other biomedical and socioeconomic factors may have contributed to these trends ${ }^{32,33}$. Screening of inmates on entry to prisons has been evaluated in Spanish and USA studies. Algorithms used on entry in these studies have generally included an initial symptom screen and TST, followed by chest radiograph if either is positive, and have shown a prevalence of active TB of 68 $2,706 / 100,000^{49-55}$. However, performing a chest radiograph (rather than an initial symptom questionnaire and TST) as the initial screening test on prison entry has been associated with a reduction of exposure time to infectious TB cases (by expediting isolation) ${ }^{53,54}$, and a reduction in cost per case diagnosed ${ }^{56}$.

\section{Coverage \& uptake of screening}

Ensuring adequate screening coverage and uptake must also be a priority for any active case finding intervention. Few studies have attempted to report coverage of screening programmes, which remains challenging to quantify in hard-to-reach groups due to the frequently mobile nature of these populations ${ }^{48,57}$. Acceptance and uptake of screening are also rarely reported, with uptake ranging from $14-87 \%$ in the absence of specific incentives ${ }^{40,41,43,58-61}$. Uptake is likely to be better with mobile (rather than off-site) screening programmes, though evidence for specific strategies to improve uptake is currently limited.

Aldridge et al. conducted a cluster randomised-controlled trial to examine whether volunteer peer educators (with direct experience of TB and/or homelessness) improved uptake of MXU screening at hostels in London. No difference in uptake was observed (40\% in the intervention group; $45 \%$ in the control group), though the study was limited by the intervention having previously been in place at 'standard care' sites prior to the study being commenced, and therefore may have resulted in residual confounding and a reduction in the difference seen between the intervention and control arms ${ }^{59}$. Other studies from the USA have shown an increase in attendance to off-site chest radiograph referral with a 
monetary incentive ${ }^{60}$ and at an initial follow-up appointment following a positive TST with either a monetary incentive, or a peer health advisor, when compared to standard care ${ }^{61}$.

\section{Yield of screening}

The weighted mean estimated number needed to screen has been estimated as 133 (range 22-1778), 1180 (4-2945) and 158 (108-252) when targeting homeless persons, prisoners and drug users respectively in low-incidence settings ${ }^{19}$. However, these estimates are heterogeneous, reflecting differences in TB incidence between different risk groups, and between different settings. Active case finding interventions therefore require a targeted, setting-specific approach. This should be based on local epidemiological data that can identify those populations with sufficient disease burden to justify the provision of resources to enable focused interventions. Policymakers may use surveillance data, or even targeted prevalence surveys, to identify high-risk populations on a local level, and determine the potential yield and thus cost-effectiveness of proposed active case finding interventions.

\section{Future directions and research priorities for active case finding interventions}

Following a 'positive' initial screening test (e.g. a mobile chest radiograph in most recent studies), the most widely utilised screening algorithm involves referral to a TB service for further investigation as the next step [Figure 1]. Sputum may be sent for microbiological testing in parallel to this referral. A problem with this approach is the risk that they may not attend the TB service for further assessment, This initial loss-to-follow-up (which occurs prior to TB diagnosis) has been estimated as being as high as $31 \%$ in London $^{37}$ and $50 \%$ in Sydney, Australia ${ }^{62}$. Implementation of 'point-of-care' molecular technology to enable a microbiological diagnosis on the day of initial screening following a suggestive chest radiograph is therefore attractive. Xpert MTB/RIF offers the potential to provide this in approximately two hours, using an automated platform ${ }^{28}$. This assay also allows the prompt identification of possible multidrug-resistance, through the detection of rifampicin-resistance conferring mutations. However, there are currently no studies published that evaluate the implementation of molecular diagnostics in a mobile outreach setting in a low-incidence country; data addressing this, including newer generations of the Xpert MTB/RIF assay or similar rapid molecular diagnostics, are therefore needed.

Technology may also be applied to MXU screening algorithms through the implementation of automated x-ray readers (e.g. CAD4TB), which may reduce reliance on trained human readers while addressing issues with inter-reader reprodubility ${ }^{63}$ [Figure 1]. However, data validating the software for use in low-incidence settings and in a mobile screening unit are required prior to widespread rollout of the technology. 
As discussed above, the variable prevalence of TB among high-risk groups in low-incidence settings means that active case finding interventions require a tailored approach based on local epidemiological data, followed by monitoring and evaluation of cost-effectiveness and impact at a local level. The roll-out of universal whole genome sequencing (WGS) in some low-incidence settings may allow this to be done with greater resolution in future. When used in combination with conventional epidemiological methods, WGS may enable surveillance systems to identify sites and individuals that carry a high-risk of onward transmission earlier and more precisely than epidemiological methods alone have allowed, particularly in the context of outbreaks ${ }^{64-66}$. Prospective studies that evaluate the potential impact of real-time genomic data on local TB control policies are awaited.

Qualitative studies have suggested that further increases in TB awareness, reduction in stigmatisation and improvements in perceived access to healthcare are all required to improve usage of TB services by risk groups ${ }^{67}$; further research is clearly needed to inform and evaluate strategies to address these needs. Engaging key partners, such as staff in prisons and shelters, is also integral to maximise uptake of screening programme targeting these groups.

In addition to identifying active TB cases, consideration of testing and treating for LTBI among highrisk groups is recommended (after exclusion of TB disease) in international and some national guidance in low-incidence settings ${ }^{68,69}$. Studies evaluating the yield of LTBI screening when implemented among risk groups in parallel to active TB case finding, along with acceptance and completion of LTBI treatment, and impact on incident TB risk are needed. Furthermore, risk groups for TB overlap with those for other diseases - including HIV, hepatitis B and hepatitis $\mathrm{C}^{70}$. Combining active case finding and linkage to care for these services for individuals in hard-to-reach groups may therefore be cost-effective by capitalising upon a shared resource infrastructure, though data to support this are currently lacking.

\section{Treatment adherence in risk groups in the TB pre-elimination era}

There have been few studies evaluating the role of interventions in improving adherence and active TB treatment completion among individuals from risk groups [Table 3]. Of these, 8 studies have evaluated enhanced case management interventions (including directly observed therapy (DOT), since this is not offered universally in low TB-incidence settings), while one has studied financial incentives. 


\section{Enhanced case management}

Three studies have evaluated interventions that involved an integrated approach of both active case finding and enhanced case management ${ }^{38,48}$. Jit et al. assessed the case management component of the London Find \& Treat service, which supports treatment completion by maintaining contact with patients during treatment, accompanying them to clinic appointments, arranging visits in community, and involving peers ${ }^{38}$. The case management service supports hard-to-reach individuals diagnosed by the service, and referred from other local TB services. The evaluation by Jit et al. found that the case management component of the service was highly cost-effective (cost $£ 4,100-£ 6,800$ per QALY gained). Treatment completion was $61.2 \%$ in the intervention cohort, compared to $51.7 \%$ with standard care after one year ${ }^{38}$.

De Vries and colleagues provided a range of enhanced case management approaches in combination with their active case finding programme in Rotterdam ${ }^{45}$. This included DOT, priority shelter accommodation, voluntary admission to TB hospitals, assistance applying for temporary residence permits, and detention as a last resort for non-compliant, infectious cases (14 patients). Incentives such as public transport tickets were also provided. They achieved treatment completion of $89.2 \%$. In Frankfurt, Germany, Goetsch et al. provided education and enhanced case management (delivered by community health workers) for drug users and homeless people diagnosed with active TB following active referral to TB services for screening, and achieved treatment completion in $76 \%{ }^{48}$.

Two studies have described enhanced cases management approaches including the provision of accommodation for homeless persons, achieving treatment completion of $80-90 \%{ }^{71,72}$, along with a reduction in the mean period of hospitalisation after introduction of the intervention and a reduction in TB incidence among homeless persons in their locality over the study period ${ }^{71}$.

Three studies have evaluated the effectiveness of DOT in improving treatment completion in a mixed hard-to-reach population. These studies demonstrated improved treatment completion with DOT compared to self-administered treatment ${ }^{73,74}$, particularly when provided in a community setting ${ }^{73}$ and when administered by peers ${ }^{75}$.

\section{Incentives}

Data on the use of financial incentives to improve adherence to therapy for TB in risk groups are lacking. In one study, Bock et al. studied the impact of financial incentives on treatment completion among a mixed hard-to-reach population in Georgia, USA, and found that DOT attendance improved 
following the introduction of a grocery voucher incentive for each DOT attendance, when compared to attendance prior to the intervention ${ }^{76}$.

\section{Future directions and research priorities for treatment adherence interventions}

Video-observed therapy (VOT) is an exciting recent development, involving patients filming themselves taking medications on a computer or mobile device, before securely transmitting these images to a remote observer ${ }^{77}$. This technology may allow enhanced case management and DOT to offer a more patient-centred approach, bridging the gap between TB patients and their healthcare providers, and reducing the need for resource-intensive face-to-face encounters. Early studies have demonstrated that VOT is both feasible and acceptable to patients receiving TB treatment in the USA and Mexico $^{78}$, and in Belarus ${ }^{79}$. A randomised-controlled trial comparing adherence to TB therapy when treatment is delivered by VOT vs. standard DOT among hard-to-reach patients in London has recently been completed with extremely promising initial results, though full published results are awaited $^{80}$.

While electronic reminder systems (e.g. short message service (SMS)) may also be of some benefit in improving adherence to appointments and treatment for TB services, the impact of such interventions on adherence and treatment completion in risk groups in low-incidence settings has not been evaluated ${ }^{81}$.

\section{Conclusions}

Vulnerable groups - including homeless persons, prisoners, high-risk drug users and other marginalised groups - are a major priority for TB control programmes in low-incidence countries due to their disproportionate disease burden, ongoing high risk of transmission, and poor treatment outcomes. Interventions targeting these groups should aim to increase timely case-detection, and improve linkage-to-care and completion of therapy.

Interventions must be tailored to address local priorities, based on knowledge of regional epidemiology and risk groups, and must be monitored and evaluated at a local level. Mobile x-ray units appear to be effective and cost-effective ${ }^{38}$ in achieving timely case-detection, and have been associated with reductions in proxy measures of transmission ${ }^{44,45}$. Implementation of new technology - including molecular diagnostics at the point-of-care (to expedite microbiological TB diagnosis), and universal whole genome sequencing (to supplement epidemiological data and identify transmission foci promptly) - may aid existing interventions to improve effectiveness in the future. 
Interventions to improve treatment completion among these risk groups must also be tailored to individuals and may include enhanced case management (by both healthcare workers and peers), the provision of supervised accommodation for homeless persons, and supervised treatment (particularly when delivered in community and by peers). Incentives may also have a role, though evidence for this among risk groups are lacking. VOT is an extremely promising technology and is currently under evaluation as a tool to improve adherence in hard-to-reach groups. Integrating both active case finding and strategies to improve adherence into outreach interventions is likely to be cost-effective, by capitalising on shared resource infrastructure, while integrating testing and treatment for other diseases with overlapping risk profiles (e.g. HIV, hepatitis B and hepatitis C) into TB outreach services may improve overall cost-effectiveness further.

However, high quality data evaluating the impact of active case finding initiatives and (in particular) interventions to improve treatment adherence among risk groups in low-incidence settings are generally lacking. More high-quality studies are required that examine the impact of such interventions on timely case-detection, treatment outcomes, risk of onward transmission, and maximising uptake of the interventions themselves. If the End TB strategy goals of achieving preelimination and moving towards elimination in low-incidence settings by 2035 are to be reached, a concerted and prolonged effort will be required to reach these vulnerable groups, engage and retain them in care to the point of treatment completion. If we are serious about elimination, these efforts must be maintained even in light of falling cost-effectiveness, as TB incidence (and thus screening yield) declines. Finally, while this review has focused on biomedical interventions that aim to reduce the burden of TB disease among risk groups, we should not forget the imperative need to address the issue at its true core. We must continue to strive to improve access to healthcare among risk groups, while also reducing the size of risk group populations themselves, by implementing policies that seek to reduce health inequity and social exclusion directly. 


\section{Box 1: Search Strategy}

A literature search was performed using Medline (1946 - September 2017) to supplement this narrative, state of the art review. In short, two search sets were created and then combined using 'and', using comprehensive search terms for (1) 'tuberculosis' and (2) 'homeless' or 'drug users' or 'prisoners' or 'vulnerable populations'. This yielded 2,317 articles. Additional articles were identified by reviewing references of included studies and review articles, and by consulting experts in the field. Original research articles investigating active case finding initiatives or interventions to promote adherence among the aforementioned risk groups in low TB-incidence settings (defined as incidence $<10 / 100,000)$ were identified. Studies that focused on contact tracing or specific outbreak investigations, or identifying and treating latent TB infection (LTBI) only, were excluded. After review of titles, abstracts and full-texts as appropriate, 45 relevant articles were identified (Tables 2 \& 3), with a narrative approach to synthesis.

\section{Box 2: Definitions (adapted from ${ }^{19,82}$ )}

Active case finding - systematic identification of people with suspected active TB in a predetermined target group.

Adherence - extent to which a patient's history of therapeutic drug-taking coincides with the prescribed treatment.

Low TB incidence country - country with annual TB incidence $\leq 10 / 100,000$ persons.

Passive case finding - a patient-initiated pathway to TB diagnosis that starts with a person presenting spontaneously to healthcare services.

Risk group - any group of people in which the prevalence or incidence of TB is significantly higher than in the general population.

Screening coverage - proportion of total eligible target population who complete screening.

Screening test - a test that distinguishes people with a high likelihood of having active TB from people who are highly unlikely to have active TB.

Screening uptake - proportion of those offered screening who complete it. 
Figure 1: Flowcharts demonstrating example screening algorithms for mobile X-ray unit service screening high-risk populations for active tuberculosis in low-incidence settings using (a) historic approach; and (b) new approach incorporating a molecular diagnostic test and automated chest radiograph reader. 'Immediate' refers to same day referral. Following referral, routine TB investigations (including microbiological confirmation) and treatment should occur via local TB services in both algorithms.

(a)

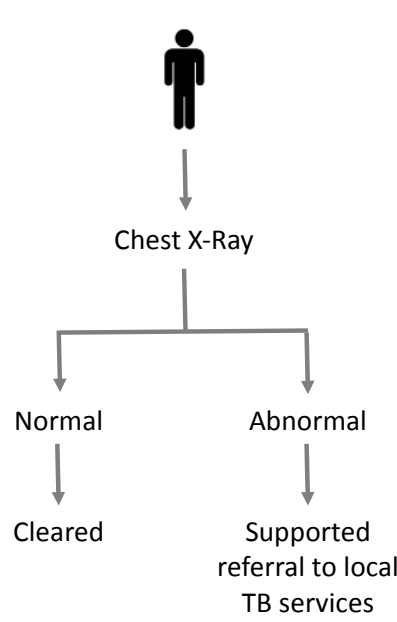

(b)

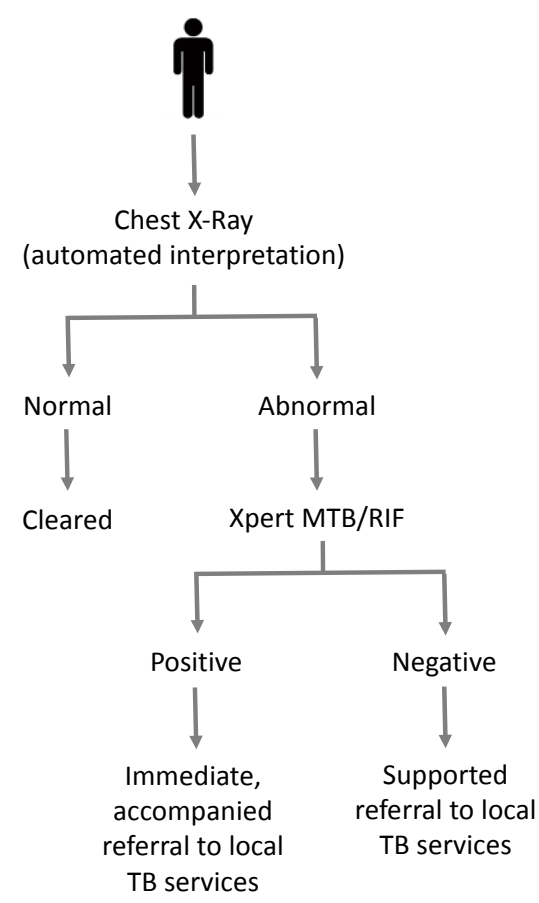


Table 1: Table summarising estimated sensitivity and specificity of currently available screening tools for active tuberculosis. Adapted from World Health Organization Systematic screening for active tuberculosis: Principles and recommendations ${ }^{19}$

\begin{tabular}{|l|c|c|}
\hline Screening tool & Sensitivity (\%) & Specificity (\%) \\
\hline Symptom screen (any symptom) & $77(68-86)$ & $68(50-85)$ \\
\hline Chest x-ray (any abnormality compatible with TB) & $98(95-100)$ & $75(72-79)$ \\
\hline Sputum-smear microscopy & $61(31-89)$ & $98(93-100)$ \\
\hline Xpert MTB/RIF & $92(70-100)$ & $99(91-100)$ \\
\hline Liquid culture (gold standard) & 100 & 100 \\
\hline
\end{tabular}


IJTLD Review: Active case finding and treatment adherence in risk groups

$$
\text { Rl (10/01/2018) }
$$

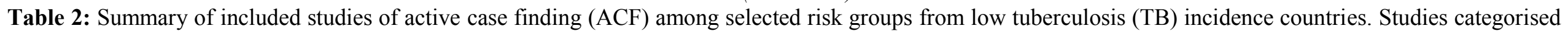

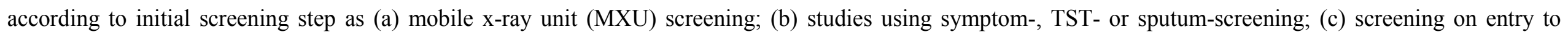

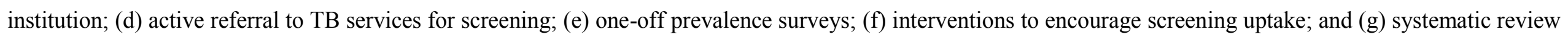
$\&$ meta-analysis / modelling. Studies listed by year of publication (reverse chronological order).

$(\mathrm{RFLP}=$ restriction fragment length polymorphism; CXR = chest X-ray; QALY = quality-adjusted life-year; CDC $=$ Centres for Disease Control and Prevention $)$

\begin{tabular}{|c|c|c|c|c|c|}
\hline Study & Year & Setting & Target population & Design, Intervention \& Comparator & Key Findings \\
\hline \multicolumn{6}{|c|}{ (a) Mobile $x$-ray unit screening } \\
\hline Bernard et al. ${ }^{44}$ & 2012 & Paris, France & Homeless people & $\begin{array}{l}\text { Observational evaluation of 14-year MXU ACF programme in } 28 \\
\text { shelters. No comparator arm. }\end{array}$ & $\begin{array}{l}179 \text { TB cases / approx. } 22,000 \text { screened; reduction in case- } \\
\text { clustering using RFLP from } 75 \% \text { to } 30 \%(p<0.01)\end{array}$ \\
\hline Story et al. ${ }^{83}$ & 2012 & London, UK & $\begin{array}{l}\text { Mixed (homeless, drug } \\
\text { users, prisoners, asylum- } \\
\text { seekers) }\end{array}$ & $\begin{array}{l}\text { Observational evaluation of MXU screening programme. } \\
\text { Compared to passively-detected cases identified through } \\
\text { routine surveillance. }\end{array}$ & $\begin{array}{l}\text { Sensitivity of CXR } 81.8 \% \text {; specificity } 99.2 \% \text {. Cases identified } \\
\text { through screening less likely to be smear-positive than } \\
\text { passively identified cases }(p=0.022) .33 / 47,510 \text { CXRs had } \\
\text { culture-confirmed TB }(0.069 \%)\end{array}$ \\
\hline Jit et al. ${ }^{38}$ & 2011 & London, UK & $\begin{array}{l}\text { Mixed (homeless, drug } \\
\text { users, prisoners, asylum- } \\
\text { seekers) }\end{array}$ & $\begin{array}{l}\text { Observational cost-effectiveness analysis of ACF using MXU } \\
\text { intervention. Compared to passively-detected cases identified } \\
\text { through routine surveillance. }\end{array}$ & $\begin{array}{l}\text { Case-detection intervention was cost-effective ( } £ 18,000 \text { - } \\
£ 26,000 / \text { QALY gained) }\end{array}$ \\
\hline de Vries et al. ${ }^{45}$ & 2007 & $\begin{array}{l}\text { Rotterdam, } \\
\text { Netherlands }\end{array}$ & $\begin{array}{l}\text { Homeless people and drug } \\
\text { users }\end{array}$ & $\begin{array}{l}\text { Observational evaluation of voluntary MXU ACF. No comparator } \\
\text { arm. }\end{array}$ & $\begin{array}{l}28 \text { TB cases identified (prevalence } 327 / 100,000 \text { CXRs), } 12 \\
\text { smear-positive; reduction in clustered cases over time using } \\
\text { RFLP ( } 80 \% \text { to } 45 \%)\end{array}$ \\
\hline Watson et al. ${ }^{37}$ & 2007 & London, UK & $\begin{array}{l}\text { Mixed (homeless, drug } \\
\text { users, prisoners, asylum- } \\
\text { seekers) }\end{array}$ & $\begin{array}{l}\text { Observational evaluation of voluntary MXU screening, } \\
\text { Compared to passively-detected cases identified through } \\
\text { routine surveillance. }\end{array}$ & $\begin{array}{l}222 / 20,357 \text { individuals screened referred; } 154 \text { (69\%) seen } \\
\text { by TB services; } 43 \text { commenced on TB treatment. Passively- } \\
\text { detected cases had almost } 3 \times \text { delay to diagnosis and risk of } \\
\text { smear-positivity than ACF cases. }\end{array}$ \\
\hline Southern et al. ${ }^{42}$ & 1999 & London, UK & Homeless people & $\begin{array}{l}\text { Observational evaluation of screening with symptom } \\
\text { questionnaire, TST and CXR on-site. Lunch voucher to } \\
\text { encourage uptake. No comparator arm. }\end{array}$ & $\begin{array}{l}10 / 2,000(0.5 \%) \text { had active TB; symptom questionnaire 'not } \\
\text { useful'; } 80 \% \text { treatment completion }\end{array}$ \\
\hline Lau \& Ferson ${ }^{62}$ & 1997 & $\begin{array}{l}\text { Sydney, } \\
\text { Australia }\end{array}$ & Homeless people & $\begin{array}{l}\text { Observational evaluation of voluntary MXU ACF in } 5 \text { hostels; } \\
\text { referral to TB service if TB suspected. No comparator arm. }\end{array}$ & $\begin{array}{l}506 / 3555 \text { screened }(14.2 \%) \text { had abnormal CXR. Only } 2 \\
\text { cases of active TB }(0.05 \%) \text {. Approx. } 50 \% \text { of those with } \\
\text { abnormal chest x-ray lost to follow-up. }\end{array}$ \\
\hline
\end{tabular}


IJTLD Review: Active case finding and treatment adherence in risk groups R1 (10/01/2018)

\begin{tabular}{|c|c|c|c|c|c|}
\hline \multicolumn{6}{|c|}{$(0 / 0112018)$} \\
\hline Stevens et al. ${ }^{43}$ & 1992 & London, UK & Homeless people & $\begin{array}{l}\text { Observational evaluation of voluntary MXU screening. No } \\
\text { comparator arm. }\end{array}$ & $\begin{array}{l}547 \text { screened; screening uptake } 44 \% ; 42 \% \text { attendance at } \\
\text { follow-up for abnormal CXRs; } 0 \text { new cases of TB identified }\end{array}$ \\
\hline Capewell et al. ${ }^{39}$ & 1986 & Edinburgh, UK & Homeless & $\begin{array}{l}\text { Observational evaluation of voluntary MXU screening. } \\
\text { Compared to passively-detected cases identified through } \\
\text { routine surveillance. }\end{array}$ & $\begin{array}{l}42 / 4687(0.9 \%) \text { of CXRs had TB }(65 \% \text { of all TB cases in } \\
\text { hostel-dwellers). Fewer ACF cases were sputum smear } \\
\text { positive ( } 26 \% \text { vs. } 58 \% \text { in passively-detected) }\end{array}$ \\
\hline Patel ${ }^{40}$ & 1985 & Glasgow, UK & Homeless & $\begin{array}{l}\text { Observational evaluation of voluntary MXU screening with food } \\
\text { voucher incentive. No comparator arm. }\end{array}$ & Uptake 47\%; 133/9,132 screened had TB (1.5\%) \\
\hline \multicolumn{6}{|c|}{ (b) Studies using symptom-, TST-or sputum-screening } \\
\hline Janssens et al. ${ }^{58}$ & 2017 & $\begin{array}{l}\text { Geneva, } \\
\text { Switzerland }\end{array}$ & Homeless people & $\begin{array}{l}\text { Observational evaluation of screening with questionnaire } \\
\text { (symptoms, epidemiological risk). Chest } x \text {-ray screening } \\
\text { performed if score }>10 \text {. No comparator arm. }\end{array}$ & $\begin{array}{l}\text { Uptake } 87.3 \% ; 30 / 726 \text { ( } 4.1 \%) \text { positive questionnaire; 0/24 } \\
\text { referred for testing had active TB }\end{array}$ \\
\hline Jensen et al. ${ }^{27}$ & 2015 & $\begin{array}{l}\text { Copenhagen, } \\
\text { Denmark }\end{array}$ & $\begin{array}{l}\text { Mixed (homeless persons; } \\
\text { persons with alcohol and/or } \\
\text { substance abuse; and } \\
\text { other socially marginalised } \\
\text { persons) }\end{array}$ & $\begin{array}{l}\text { Observational evaluation of screening using sputum microscopy } \\
\& \text { culture at } 11 \text { locations, on } 7 \text { occasions. No comparator arm. }\end{array}$ & $\begin{array}{l}36 / 1075 \text { had TB. } 24 \text { cases identified at first screening of } \\
\text { each participant (prevalence } 2233 / 100000) \text {. } 35 / 36(97.2 \%) \\
\text { TB cases culture-positive; } 7 / 36(19.4 \%) \text { smear-positive; } \\
28 / 36(77.8 \%) \text { had chest X-ray suggestive of TB. } 30 / 36 \\
(83.3 \%) \text { had a successful outcome. }\end{array}$ \\
\hline McAdam et al. ${ }^{32}$ & 2009 & $\begin{array}{l}\text { New York } \\
\text { City, USA }\end{array}$ & As McAdam et al., 2009 & $\begin{array}{l}\text { Observational evaluation of screening with symptom } \\
\text { questionnaire \& TST. Sputum smear \& culture, and CXR if TST- } \\
\text { positive (or previous TST or active TB). No comparator arm. }\end{array}$ & $\begin{array}{l}\text { Coverage } 3-13.9 \% \text { of homeless population. } 63 / 28,835 \text { active } \\
\text { TB }(0.24 \%) \text {. Incidence fell from } 1,502 / 100,000(1992) \text { to } \\
171 / 100,000 \text { (2004) }\end{array}$ \\
\hline Miller et al. ${ }^{31}$ & 2006 & Texas, USA & $\begin{array}{l}\text { Homeless people and } \\
\text { prisoners (parallel } \\
\text { interventions compared) }\end{array}$ & $\begin{array}{l}\text { Observational evaluation of screening with symptom } \\
\text { questionnaire \& TST. Further investigations if TST positive. } \\
\text { Selection for homeless screening unclear. Cases treated under } \\
\text { DOT. Incentives for treatment provided for homeless (dietary } \\
\text { supplements or fast-food coupons). No comparator arm. }\end{array}$ & $\begin{array}{l}\text { Homeless }-10 / 822 \text { active TB }(1.2 \%) \text {; prisoners } 7 / 22,920 \\
\text { active TB }(0.03) \text {. Estimated that LTBI treatment of homeless } \\
\text { persons and jail inmates will avert } 11.9 \text { and } 7.9 \text { TB cases at } \\
\text { a cost of } \$ 14,350 \text { and } \$ 34,761 \text { per TB case, respectively }\end{array}$ \\
\hline Kong et al. ${ }^{33}$ & 2002 & Denver, USA & $\begin{array}{l}\text { Homeless people and drug } \\
\text { users }\end{array}$ & $\begin{array}{l}\text { Observational evaluation of screening with symptom screen \& } \\
\text { TST at } 4 \text { shelters and } 6 \text { drug recovery programmes. If either } \\
\text { positive, referral to TB service. Screening required to stay at } \\
\text { shelter / drug programme. No comparator arm. }\end{array}$ & $\begin{array}{l}\text { Estimated TB incidence among all homeless decreased from } \\
510 \text { to } 121 \text { cases / 100,000 / year during intervention years. } \\
\text { Recent transmission (DNA fingerprinting definition) } \\
\text { decreased from } 49 \% \text { to } 14 \%(\mathrm{p}=0.03) \text {. }\end{array}$ \\
\hline
\end{tabular}


IJTLD Review: Active case finding and treatment adherence in risk groups

$$
\text { R1 (10/01/2018) }
$$

\begin{tabular}{|c|c|c|c|c|c|}
\hline \\
\hline Griffin \& Hoff ${ }^{30}$ & 1999 & Kansas, USA & Homeless people & $\begin{array}{l}\text { Observational evaluation of screening with TST screening; CXR } \\
\text { in TST positive cases. No comparator arm. }\end{array}$ & 0 cases of active TB; $89 / 856$ TST positive \\
\hline Kimerling et al. ${ }^{84}$ & 1999 & $\begin{array}{l}\text { Birmingham, } \\
\text { USA }\end{array}$ & Homeless people & $\begin{array}{l}\text { Observational evaluation of screening with sputum culture, } \\
\text { symptom screen (and TST in round 1/4) for overnight clients. No } \\
\text { comparator arm. }\end{array}$ & $\begin{array}{l}4 / 127 \text { screened }(3.1 \%) \text { had TB. } 3 / 4 \text { clustered using RFLP. } \\
\text { Costs estimated to be } \$ 1311 / \text { case identified. Only } 1 / 4 \text { cases } \\
\text { reported productive cough on symptoms screen }\end{array}$ \\
\hline McAdam et al. ${ }^{85}$ & 1990 & $\begin{array}{l}\text { New York } \\
\text { City, USA }\end{array}$ & $\begin{array}{l}\text { Homeless people attending } \\
\text { shelter clinic (for work } \\
\text { programme clearance or } \\
\text { for evaluation of any } \\
\text { medical problem) }\end{array}$ & $\begin{array}{l}\text { Observational evaluation of screening with symptom } \\
\text { questionnaire \& TST. Sputum smear \& culture, and CXR if TST- } \\
\text { positive (or previous TST or active TB). No comparator arm. }\end{array}$ & 100/1,853 (6\%) had active TB. Treatment completion 36\% \\
\hline \multicolumn{6}{|c|}{ (c) Screening on entry to institution } \\
\hline Rutz et al. ${ }^{51}$ & 2008 & $\begin{array}{l}\text { Baltimore, } \\
\text { USA }\end{array}$ & Prisoners & $\begin{array}{l}\text { Cross-sectional evaluation of adherence to CDC TB control } \\
\text { policy. Symptom screen and TST on arrival (as per CDC } \\
\text { guidance); if either positive, referral for CXR and clinical } \\
\text { evaluation. No comparator arm. }\end{array}$ & $\begin{array}{l}28 / 97 \text { of intake health interviews conducted correctly. Delays } \\
\text { noted in diagnostic testing of } 51 \text { detainees isolated for } \\
\text { suspected TB. }\end{array}$ \\
\hline Saunders et al. ${ }^{86}$ & 2001 & $\begin{array}{l}\text { San Diego, } \\
\text { USA }\end{array}$ & Prisoners & $\begin{array}{l}\text { Observational evaluation of screening with symptom review, } \\
\text { TST, and CXR for all new entrants. Compared to previous policy } \\
\text { of only symptoms review and TST. }\end{array}$ & $\begin{array}{l}8 / 1,830 \text { screened with universal CXR had TB (no change in } \\
\text { incidence from previous practice). CXR screening of all } \\
\text { inmates reduced exposure time to active TB cases by } 75 \%\end{array}$ \\
\hline Solsona et al. ${ }^{87}$ & 2001 & $\begin{array}{l}\text { Barcelona, } \\
\text { Spain }\end{array}$ & Homeless people & $\begin{array}{l}\text { Observational evaluation of screening with TST, CXR and } \\
\text { sputum (if CXR suggestive) in people entering shelters. No } \\
\text { comparator arm. }\end{array}$ & 5/447 (1.1\%) had active TB; 335 (75\%) had LTBI \\
\hline White et al. ${ }^{55}$ & 2001 & $\begin{array}{l}\text { San } \\
\text { Francisco, } \\
\text { USA }\end{array}$ & Prisoners & $\begin{array}{l}\text { Observational evaluation of screening with symptom screen and } \\
\text { TST on arrival (as per CDC guidance); if either positive, referral } \\
\text { for CXR and clinical evaluation. No comparator arm. }\end{array}$ & $\begin{array}{l}\text { In } 1994,25 \text { active TB cases booked into the jail (prevalence } \\
78.5 / 100,000) \text {; only } 3 / 25 \text { were new diagnoses. In 1998, } 21 \\
\text { active TB cases booked in (prevalence } 72.1 / 100 \text { 000); only } \\
7 / 21 \text { new diagnoses. }\end{array}$ \\
\hline Brock et al. ${ }^{52}$ & 1998 & Georgia, USA & Prisoners & $\begin{array}{l}\text { Observational evaluation of screening with symptom screen and } \\
\text { TST on arrival (as per CDC guidance); if either positive, referral } \\
\text { for CXR and clinical evaluation. No comparator arm. }\end{array}$ & $\begin{array}{l}142 \text { TB cases identified; } 74 \% \text { detected through screening. } \\
38 \% \text { lost-to-follow-up }\end{array}$ \\
\hline Puisis et al. ${ }^{54}$ & 1996 & Chicago, USA & Prisoners & $\begin{array}{l}\text { Observational evaluation of screening with miniature CXR on } \\
\text { arrival. Compared to previous approach using TST screening. }\end{array}$ & $\begin{array}{l}86 / 126,608(0.07 \%) \text { screened had TB; } 67 \text { diagnosed by X- } \\
\text { ray and } 19 \text { by diagnostic work-up. Mean time from entry to } \\
\text { isolation reduced from } 17.6 \text { days with TST screening to } 2.3 \\
\text { days with CXR screening. }\end{array}$ \\
\hline
\end{tabular}


IJTLD Review: Active case finding and treatment adherence in risk groups

$$
R 1(10 / 01 / 2018)
$$

\begin{tabular}{|c|c|c|c|c|c|}
\hline $\begin{array}{l}\text { Martin-Sanchez } \\
\text { et al. }{ }^{49}\end{array}$ & 1995 & $\begin{array}{l}\text { Northwest } \\
\text { Spain }\end{array}$ & Prisoners & $\begin{array}{l}\text { Observational evaluation of screening with TST. CXR if TST- } \\
\text { positive or HIV-positive. Sputum microscopy/culture if CXR } \\
\text { abnormal. No comparator arm. }\end{array}$ & $\begin{array}{l}\text { TB diagnosed in } 12 / 944(1.26 \%) \text {; only } 4 / 12 \text { cases were new } \\
\text { diagnoses via screening }\end{array}$ \\
\hline Martin et al..$^{50}$ & 1994 & $\begin{array}{l}\text { Barcelona, } \\
\text { Spain }\end{array}$ & Prisoners & $\begin{array}{l}\text { Observational evaluation of screening with TST. CXR if TST or } \\
\text { HIV-positive. Sputum microscopy/culture if CXR abnormal. No } \\
\text { comparator arm. }\end{array}$ & 19/702 (2.7\%) who completed screening had TB \\
\hline Bellin et al. ${ }^{88}$ & 1993 & $\begin{array}{l}\text { New York } \\
\text { City, USA }\end{array}$ & $\begin{array}{l}\text { Persons admitted to an } \\
\text { opiate detoxification unit in } \\
\text { an urban jail }\end{array}$ & $\begin{array}{l}\text { Observational evaluation of screening with TST \& CXR } \\
\text { screening. No comparator arm. }\end{array}$ & 73/1,314 had CXR changes consistent with active TB \\
\hline \multicolumn{6}{|c|}{ (d) Active referral to TB services for screening } \\
\hline $\begin{array}{l}\text { Jimenez- } \\
\text { Fuentes et al. }{ }^{47}\end{array}$ & 2014 & $\begin{array}{l}\text { Barcelona, } \\
\text { Spain }\end{array}$ & $\begin{array}{l}\text { Drug users, 'economically } \\
\text { disadvantaged' \& recent } \\
\text { migrants from } \\
\text { hyperendemic countries }\end{array}$ & $\begin{array}{l}\text { Observational evaluation of referral to TB service for clinical } \\
\text { evaluation and chest X-ray screening (from various referral } \\
\text { sources). No comparator arm. }\end{array}$ & $\begin{array}{l}30 / 5,982 \text { screened had TB }(0.5 \%) \text {. Prevalence } 1.77 \% \text { in } \\
\text { recent migrants; } 0.30 \% \text { in economically disadvantaged; } \\
0.62 \% \text { in drug users }\end{array}$ \\
\hline Goetsch et al. ${ }^{48}$ & 2012 & $\begin{array}{l}\text { Frankfurt, } \\
\text { Germany }\end{array}$ & $\begin{array}{l}\text { Drug users and homeless } \\
\text { persons }\end{array}$ & $\begin{array}{l}\text { Observational evaluation of referral for departmental CXR } \\
\text { screening by community health workers. No comparator arm. }\end{array}$ & $\begin{array}{l}\text { Screening coverage } 18-26 \% ; 39 / 3477 \text { screened had TB } \\
(1.1 \%)\end{array}$ \\
\hline \multicolumn{6}{|c|}{ (e) One-off prevalence surveys } \\
\hline Badiaga et al. ${ }^{89}$ & 2009 & $\begin{array}{l}\text { Marseilles, } \\
\text { France }\end{array}$ & Homeless people & $\begin{array}{l}\text { Observational evaluation of comprehensive, multidisciplinary } \\
\text { screening of participants including symptom screen, sputum } \\
\text { microscopy \& culture, chest radiograph. No comparator arm. }\end{array}$ & $2 / 221(1 \%)$ had TB \\
\hline Kumar et al. ${ }^{41}$ & 1995 & London, UK & Homeless people & $\begin{array}{l}\text { Observational evaluation of symptom \& CXR screening for two } \\
\text { years. In year one, CXR only if symptomatic. In year two, chest } \\
\text { x-ray universal. No comparator arm. }\end{array}$ & $\begin{array}{l}595 / 3600(16.5 \%) \text { accepted screening; } 30 / 595(5 \%) \text { had } \\
\text { changes suggestive of active tuberculosis. } 9 / 595(1.5 \%) \text { had } \\
\text { confirmed TB; } 13 \text { did not attend follow-up }\end{array}$ \\
\hline Barry et al. ${ }^{90}$ & 1986 & Boston, USA & Homeless people & $\begin{array}{l}\text { Observational evaluation of one-off active case finding with } \\
\text { TST, CXR, sputum culture over 4-night period. No comparator } \\
\text { arm. }\end{array}$ & $3 / 586(0.5 \%)$ had confirmed TB \\
\hline \multicolumn{6}{|c|}{ (f) Interventions to encourage screening uptake } \\
\hline Aldridge et al. ${ }^{59}$ & 2015 & London, UK & Homeless people & $\begin{array}{l}\text { Cluster RCT ( } 46 \text { hostels; } 2,342 \text { participants) of volunteer peer } \\
\text { educators to encourage MXU screening uptake. Compared to } \\
\text { standard care. }\end{array}$ & $\begin{array}{l}\text { No difference in uptake between peer educator (median } \\
40 \% \text { ) and control (median } 45 \% \text { ) hostels }\end{array}$ \\
\hline Perlman et al. ${ }^{60}$ & 2003 & $\begin{array}{l}\text { New York } \\
\text { City, USA }\end{array}$ & $\begin{array}{l}\text { Drug users attending } \\
\text { needle-exchange } \\
\text { programme }\end{array}$ & $\begin{array}{l}\text { Observational evaluation of monetary incentive to attend } \\
\text { external chest x-ray screening (if TST positive). Compared to } \\
\text { historical approach with no monetary incentive. }\end{array}$ & $\begin{array}{l}\text { Adherence to CXR referral within } 7 \text { days } 79 \% \text { with monetary } \\
\text { incentive vs. } 14 \% \text { without }(p<.0001) \text {. Median time to CXR } \\
\text { shorter among those given incentive ( } 2 \text { vs. } 11 \text { days; } p< \\
.0001 \text { ) }\end{array}$ \\
\hline
\end{tabular}


IJTLD Review: Active case finding and treatment adherence in risk groups R1 (10/01/2018)

\begin{tabular}{|c|c|c|c|c|c|}
\hline Pilote et al. ${ }^{61}$ & 1996 & $\begin{array}{l}\text { San } \\
\text { Francisco, } \\
\text { USA }\end{array}$ & Homeless people & $\begin{array}{l}\text { RCT of monetary incentives vs peer health advisor vs standard } \\
\text { care to encourage TST positive people to attend TB clinic for } \\
\text { further screening. }\end{array}$ & $\begin{array}{l}69(84 \%) \text { with monetary incentive completed first follow-up } \\
\text { appointment, vs. } 62(75 \%) \text { with peer health adviser vs } 42 \\
(53 \%) \text { with usual care. } 3 / 173(1.7 \%) \text { screened had active TB }\end{array}$ \\
\hline Paquette et al..$^{22}$ & 2014 & N/A & Homeless people & Systematic review and meta-analysis of CXR screening & $\begin{array}{l}\text { Pooled prevalence of active TB in } 16 \text { study cohorts } \\
931 / 100,000 \text { population screened. } 6 / 7 \text { longitudinal screening } \\
\text { programs reported reduction in regional TB incidence after } \\
\text { implementation }\end{array}$ \\
\hline van Hest et al. ${ }^{57}$ & 2008 & $\begin{array}{l}\text { Rotterdam, } \\
\text { Netherlands }\end{array}$ & $\begin{array}{l}\text { Homeless people and drug } \\
\text { users }\end{array}$ & $\begin{array}{l}\text { Modelling study using truncated models to estimate coverage of } \\
\text { MXU ACF }\end{array}$ & $\begin{array}{l}\text { Screening programme reached approx. } 2 / 3 \text { of estimated } \\
\text { target population at least annually }\end{array}$ \\
\hline Brewer et al. ${ }^{91}$ & 2001 & USA & Homeless people & $\begin{array}{l}\text { Modelling study in US homeless populations using computer- } \\
\text { based simulation model to examine impact of TB-control } \\
\text { strategies on projected TB cases and deaths. }\end{array}$ & $\begin{array}{l}10 \% \text { increase in access to treatment among homeless } \\
\text { persons with active TB produced largest declines in } \\
\text { predicted TB cases and deaths after } 10 \text { years }\end{array}$ \\
\hline $\begin{array}{l}\text { Jones \& } \\
\text { Schaffner }\end{array}$ & 2001 & USA & Prisoners & $\begin{array}{l}\text { Cost-effectiveness analysis using primary data from literature } \\
\text { review of miniature CXR screening. }\end{array}$ & $\begin{array}{l}\text { Cost of screening with miniature chest radiography } \\
\text { estimated as } \$ 9,600 / \text { case identified }\end{array}$ \\
\hline
\end{tabular}


IJTLD Review: Active case finding and treatment adherence in risk groups

$$
\text { R1 (10/01/2018) }
$$

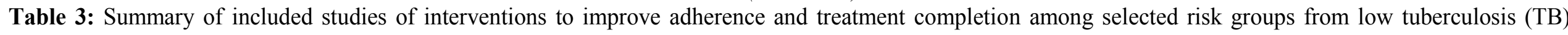

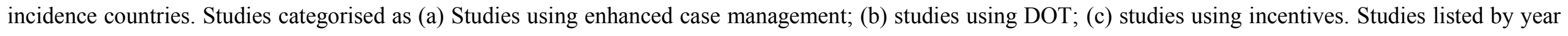
of publication (reverse chronological order).

$(\mathrm{ACF}=$ active case finding; DOT $=$ directly observed therapy).

\begin{tabular}{|c|c|c|c|c|c|}
\hline Study & Year & Setting & Target population & Design, Intervention \& Comparator & Key findings \\
\hline \multicolumn{6}{|c|}{ (a) Studies using enhanced case management } \\
\hline Goetsch et al. ${ }^{48}$ & 2012 & Frankfurt, Germany & $\begin{array}{l}\text { Drug users and homeless } \\
\text { persons }\end{array}$ & $\begin{array}{l}\text { Observational evaluation of enhanced case management, } \\
\text { hospital admission for initiation of treatment. No comparator } \\
\text { arm. }\end{array}$ & Treatment completion $76 \%$ \\
\hline Jit et al. ${ }^{38}$ & 2011 & London, UK & $\begin{array}{l}\text { Mixed (including homeless } \\
\text { people, prisoners, drug } \\
\text { users, asylum seekers) }\end{array}$ & $\begin{array}{l}\text { Observational evaluation of enhanced case management with } \\
\text { treatment support by peers. Compared to passively detected } \\
\text { cases (from routine surveillance). }\end{array}$ & $\begin{array}{l}\text { Case-management highly cost-effective ( } ₫ 4100- \\
\text { £6800/QALY gained). Treatment completion } 61.2 \% \text { (vs. } \\
51.7 \% \text { ) in case management cohort. }\end{array}$ \\
\hline de Vries et al..$^{45}$ & 2007 & $\begin{array}{l}\text { Rotterdam, } \\
\text { Netherlands }\end{array}$ & $\begin{array}{l}\text { Homeless people and drug } \\
\text { users }\end{array}$ & $\begin{array}{l}\text { Observational evaluation of DOT, and a range of other } \\
\text { enhanced case management approaches including } \\
\text { priority shelter accommodation, voluntary admission to TB } \\
\text { hospitals, assistance applying for temporary residence permits. } \\
\text { Detention as a last resort (14 patients). Incentives such as public } \\
\text { transport tickets also provided. No comparator arm. }\end{array}$ & Treatment completion $89.2 \%$ \\
\hline LoBue et al. ${ }^{72}$ & 1999 & San Diego, USA & Homeless persons & $\begin{array}{l}\text { Observational evaluation of DOT and supervised } \\
\text { accommodation provided. No comparator arm. }\end{array}$ & $\begin{array}{l}\text { Treatment completion achieved in } 18 / 20 \text { cases. Cost } \\
\text { savings for infectious patients estimated as } \$ 27,034 \text { per } \\
\text { patient. }\end{array}$ \\
\hline Diez et al. ${ }^{71}$ & 1996 & Barcelona, Spain & Homeless people & $\begin{array}{l}\text { Observational evaluation of DOT, primary health care \& } \\
\text { accommodation. Compared with historical trends. }\end{array}$ & $\begin{array}{l}\text { Decrease in local TB incidence among homeless (from } 32.4 \\
\text { to } 19.8 \text { per } 100,000 \text { from } 1987-1992 ; p=0.03 \text { ). } 19.6 \% \text { of } \\
\text { patients failed to complete treatment, and decrease in } \\
\text { mean period of hospitalization from } 27.1 \text { to } 15.7 \text { days from } \\
1986-1992\end{array}$ \\
\hline \multicolumn{6}{|c|}{ (b) Studies using DOT } \\
\hline Ricks et al. ${ }^{75}$ & 2015 & Chicago, USA & Drug users & $\begin{array}{l}\text { RCT. Substance users randomized to DOT administered by } \\
\text { either 1) public health personnel (standard arm) or 2) previous } \\
\text { substance-using or HIV/AIDS outreach workers (enhanced arm) }\end{array}$ & $\begin{array}{l}\text { Standard arm had a significantly higher risk of non- } \\
\text { completion of treatment (39\% vs. 15\%) }\end{array}$ \\
\hline Kim et al. ${ }^{73}$ & 2007 & Chicago, USA & Prisoners & Observational comparison of those who received DOT vs those & DOT associated with higher treatment completion (59\% vs \\
\hline
\end{tabular}


IJTLD Review: Active case finding and treatment adherence in risk groups R1 (10/01/2018)

\begin{tabular}{|c|c|c|c|c|c|}
\hline \multicolumn{6}{|c|}{$K 1(10 / 01 / 2010)$} \\
\hline & & & & who did not. & $\begin{array}{l}\text { 29.1\%); higher if DOT in community ( } 70.8 \% \text { field DOT vs } \\
43.5 \% \text { clinic DOT) }\end{array}$ \\
\hline Juan et al. ${ }^{74}$ & 2006 & Valencia, Spain & $\begin{array}{l}\text { Mixed population at risk } \\
\text { for non-adherence (HIV, } \\
\text { alcoholism, drug use, } \\
\text { immigrant or homeless } \\
\text { and/or previous failure to } \\
\text { complete) }\end{array}$ & $\begin{array}{l}\text { Observational evaluation of pharmacy-delivered DOT compared } \\
\text { to historic self-administration cohort }\end{array}$ & $\begin{array}{l}\text { Treatment completion } 75.2 \% \text { in DOT group, vs. } 26.7 \% \text { self- } \\
\text { administration group }(P<0.001) \text {. DOT increased cost of } \\
\text { treatment by } 400 \text { Euros. }\end{array}$ \\
\hline \multicolumn{6}{|c|}{ (c) Studies using incentives } \\
\hline Bock et al. ${ }^{76}$ & 2001 & Georgia, USA & $\begin{array}{l}\text { Mixed, non-adherent TB } \\
\text { cases (inc homeless, } \\
\text { alcohol/drug-dependence, } \\
\text { HIV) }\end{array}$ & $\begin{array}{l}\text { Observational evaluation of } \$ 5 \text { grocery voucher for each kept } \\
\text { DOT attendance. Compared to historical cohort. }\end{array}$ & $\begin{array}{l}\text { Improved adherence to DOT in intervention cohort (60 vs } \\
19 \% \text { ) }\end{array}$ \\
\hline
\end{tabular}




\section{References}

1 World Health Organization. The End TB Strategy. 2015.

http://www.who.int/tb/strategy/End_TB_Strategy.pdf?ua=1 (accessed Oct 1, 2017).

2 World Health Organization. Towards tuberculosis elimination: an action framework for lowincidence countries. 2014.

http://apps.who.int/iris/bitstream/10665/132231/1/9789241507707_eng.pdf (accessed Oct 6, 2017).

3 European Centre for Disease Prevention and Control. Guidance on tuberculosis control in vulnerable and hard-to-reach populations. 2016.

https://ecdc.europa.eu/sites/portal/files/media/en/publications/Publications/TB-guidanceinterventions-vulnerable-groups.pdf (accessed Sept 25, 2017).

4 de Vries G, Aldridge R, Caylà J, et al. Epidemiology of tuberculosis in big cities of the European Union and European Economic Area countries. Eurosurveillance 2014; 19: 20726.

5 Beijer U, Wolf A, Fazel S. Prevalence of tuberculosis, hepatitis C virus, and HIV in homeless people: a systematic review and meta-analysis. Lancet Infect Dis 2012; 12: 859-70.

Dolan K, Wirtz AL, Moazen B, et al. Global burden of HIV, viral hepatitis, and tuberculosis in prisoners and detainees. Lancet (London, England) 2016; 388: 1089-102.

7 Story A, Murad S, Roberts W, Verheyen M, Hayward AC, Network LTN. Tuberculosis in London: the importance of homelessness, problem drug use and prison. Thorax 2007; 62: 66771.

8 Lonnroth K, Williams BG, Stadlin S, Jaramillo E, Dye C. Alcohol use as a risk factor for tuberculosis - a systematic review. BMC Public Health 2008; 8: 289.

9 Rehm J, Samokhvalov A V, Neuman MG, et al. The association between alcohol use, alcohol use disorders and tuberculosis (TB). A systematic review. BMC Public Health 2009; 9: 450.

10 Gardy JL, Johnston JC, Ho Sui SJ, et al. Whole-genome sequencing and social-network analysis of a tuberculosis outbreak. N Engl J Med 2011; 364: 730-9.

11 Crisan A, Wong HY, Johnston JC, et al. Spatio-temporal analysis of tuberculous infection risk among clients of a homeless shelter during an outbreak. Int J Tuberc Lung Dis 2015; 19: 1033-iii.

12 de Vries G, van Hest RA. From contact investigation to tuberculosis screening of drug addicts and homeless persons in Rotterdam. Eur J Public Health 2006; 16: 133-6.

13 Lonnroth K, Williams BG, Cegielski P, Dye C. A consistent log-linear relationship between tuberculosis incidence and body mass index. Int J Epidemiol 2010; 39: 149-55.

14 Winter J et al. Full reference TBC. Int J Tuberc Lung Dis 2017.

15 Lönnroth K, Jaramillo E, Williams BG, Dye C, Raviglione M. Drivers of tuberculosis epidemics: The role of risk factors and social determinants. Soc Sci Med 2009; 68: 2240-6. 
16 Story A, Bothamley G, Hayward A. Crack cocaine and infectious tuberculosis. Emerg Infect Dis 2008; 14: 1466-9.

17 Vries G De, Hest RA Van. From contact investigation to tuberculosis screening of drug addicts and homeless persons in Rotterdam. 2017; 16: 133-6.

18 Menzies N. Full reference TBC. Int J Tuberc Lung Dis 2017.

19 World Health Organization. Systematic screening for active tuberculosis: Principles and Recommendations. 2013.

http://apps.who.int/iris/bitstream/10665/84971/1/9789241548601_eng.pdf?ua=1\&ua=1 (accessed Oct 10, 2017).

20 Yates S, Story A, Hayward A. Screening prisoners for Tuberculosis: What should the UK do? [Poster]. Thorax 2009; 64 Suppl 4: A105.

21 Raviglione MC, Pio A. Evolution of WHO policies for tuberculosis control, 1948-2001. Lancet (London, England) 2002; 359: 775-80.

22 Paquette K, Cheng MP, Kadatz MJ, Cook VJ, Chen W, Johnston JC. Chest radiography for active tuberculosis case finding in the homeless: a systematic review and meta-analysis. Int $J$ Tuberc Lung Dis 2014; 18: 1231-6.

23 Zenner D, Southern J, Van Hest R, et al. Active case finding for tuberculosis among high-risk groups in low-incidence countries. Int J Tuberc Lung Dis 2013; 17: 573-82.

24 Iademarco MF, O'Grady J, Lönnroth $\mathrm{K}$. Chest radiography for tuberculosis screening is back on the agenda [Editorial]. Int J Tuberc Lung Dis 2012; 16: 1421-2.

25 Abubakar I, Story A, Lipman M, et al. Diagnostic accuracy of digital chest radiography for pulmonary tuberculosis in a UK urban population. Eur Respir J 2010; 35: 689-92.

26 Lawn SD, Wood R. Tuberculosis in antiretroviral treatment services in resource-limited settings: addressing the challenges of screening and diagnosis. J Infect Dis 2011; 204 Suppl: S1159-67.

27 Jensen SG, Olsen NW, Seersholm N, et al. Screening for TB by sputum culture in high-risk groups in Copenhagen, Denmark: a novel and promising approach. Thorax 2015; 70: 979-83.

28 World Health Organization. Xpert MTB/RIF assay for the diagnosis of pulmonary and extrapulmonary TB in adults and children. 2013.

http://apps.who.int/iris/bitstream/10665/112472/1/9789241506335_eng.pdf?ua=1 (accessed Jan 28, 2015).

29 UNITAID. Tuberculosis Diagnostics Technology Landscape 5th Edition, May 2017. 2017. https://unitaid.eu/assets/2017-Unitaid-TB-Diagnostics-Technology-Landscape.pdf (accessed Oct 24, 2017).

30 Griffin RG, Hoff GL. Tuberculosis screening in Kansas City homeless shelters. Mo Med 1999; 96: 496-9.

31 Miller TL, Hilsenrath P, Lykens K, McNabb SJN, Moonan PK, Weis SE. Using cost and 
health impacts to prioritize the targeted testing of tuberculosis in the United States. Ann Epidemiol 2006; 16: 305-12.

32 McAdam JM, Bucher SJ, Brickner PW, Vincent RL, Lascher S. Latent tuberculosis and active tuberculosis disease rates among the homeless, New York, New York, USA, 1992-2006. Emerg Infect Dis 2009; 15: 1109-11.

33 Kong P-M, Tapy J, Calixto P, et al. Skin-test screening and tuberculosis transmission among the homeless. Emerg Infect Dis 2002; 8: 1280-4.

34 Lalvani A. IGRA in Diagnostic Evaluation of Active TB (IDEA). 2017. https://www.journalslibrary.nihr.ac.uk/programmes/hta/0810602\#/documentation (accessed Oct 24, 2017).

35 Sester M, Sotgiu G, Lange C, et al. Interferon- release assays for the diagnosis of active tuberculosis: a systematic review and meta-analysis. Eur Respir J 2011; 37: 100-11.

36 Story A, Aldridge RW, Abubakar I, et al. Active case finding for pulmonary tuberculosis using mobile digital chest radiography: an observational study. Int J Tuberc Lung Dis 2012; 16: $1461-7$.

37 Watson J, Abubakar I, Story A, et al. Mobile targeted digital chest radiography in the control of tuberculosis among hard to reach groups. London: Health Protection Agency Centre for Infections, Department of Health. 2007.

38 Jit M, Stagg HR, Aldridge RW, White PJ, Abubakar I. Dedicated outreach service for hard to reach patients with tuberculosis in London: observational study and economic evaluation. $B M J$ 2011; 343: d5376-d5376.

39 Capewell S, France AJ, Anderson M, Leitch AG. The diagnosis and management of tuberculosis in common hostel dwellers. Tubercle 1986; 67: 125-31.

40 Patel KR. Pulmonary tuberculosis in residents of lodging houses, night shelters and common hostels in Glasgow: a 5-year prospective survey. Br J Dis Chest 1985; 79: 60-6.

41 Kumar D, Citron KM, Leese J, Watson JM. Tuberculosis among the homeless at a temporary shelter in London: report of a chest $\mathrm{x}$ ray screening programme. J Epidemiol Community Health 1995; 49: 629-33.

42 Southern A, Premaratne N, English M, Balazs J, O'Sullivan D. Tuberculosis among homeless people in London: an effective model of screening and treatment. Int J Tuberc Lung Dis 1999; 3: $1001-8$.

43 Stevens A, Bickler G, Jarrett L, Bateman N. The public health management of tuberculosis among the single homeless: is mass miniature $\mathrm{x}$ ray screening effective?. J Epidemiol Community Health 1992; 46: 141-3.

44 Bernard C, Sougakoff W, Fournier A, et al. Impact of a 14-year screening programme on tuberculosis transmission among the homeless in Paris. Int J Tuberc Lung Dis 2012; 16: 64955. 
de Vries G, van Hest RAH, Richardus JH. Impact of mobile radiographic screening on tuberculosis among drug users and homeless persons. Am J Respir Crit Care Med 2007; 176: $201-7$.

van Hest R, de Vries G. Active tuberculosis case-finding among drug users and homeless persons: after the outbreak. Eur Respir J 2016; 48: 269-71. Jimenez-Fuentes MA, Auge CM, Gomez MNA, et al. Screening for active tuberculosis in high-risk groups. Int J Tuberc Lung Dis 2014; 18: 1459-65. Goetsch U, Bellinger OK, Buettel K-L, Gottschalk R. Tuberculosis among drug users and homeless persons: impact of voluntary X-ray investigation on active case finding. Infection 2012; 40: 389-95.

49 Martin Sanchez V, Alvarez-Guisasola F, Cayla JA, Alvarez JL. Predictive factors of Mycobacterium tuberculosis infection and pulmonary tuberculosis in prisoners. Int $J$ Epidemiol 1995; 24: 630-6.

50 Martin V, Gonzalez P, Cayla JA, et al. Case-finding of pulmonary tuberculosis on admission to a penitentiary centre. Tuber Lung Dis 1994; 75: 49-53.

51 Rutz HJ, Bur S, Lobato MN, Baucom S, Bohle E, Baruch NG. Tuberculosis Control in a Large Urban Jail. J Public Heal Manag Pract 2008; 14: 442-7.

Brock NN, Reeves M, LaMarre M, DeVoe B. Tuberculosis case detection in a state prison system. Public Health Rep 1998; 113: 359-64.

53 Saunders DL, Olive DM, Wallace SB, Lacy D, Leyba R, Kendig NE. Tuberculosis screening in the federal prison system: an opportunity to treat and prevent tuberculosis in foreign-born populations. Public Health Rep 2001; 116: 210-8.

54 Puisis M, Feinglass J, Lidow E, Mansour M. Radiographic screening for tuberculosis in a large urban county jail. Public Health Rep 1996; 111: 330-4.

55 White MC, Tulsky JP, Portillo CJ, Menendez E, Cruz E, Goldenson J. Tuberculosis prevalence in an urban jail: 1994 and 1998. Int J Tuberc Lung Dis 2001; 5: 400-4.

56 Jones TF, Schaffner W. Miniature chest radiograph screening for tuberculosis in jails: a costeffectiveness analysis. Am J Respir Crit Care Med 2001; 164: 77-81.

57 van Hest NAH, De Vries G, Smit F, Grant AD, Richardus JH. Estimating the coverage of a targeted mobile tuberculosis screening programme among illicit drug users and homeless persons with truncated models. Epidemiol Infect 2008; 136: 628-35. Janssens J-P, Wuillemin T, Adler D, Jackson Y. Screening for tuberculosis in an urban shelter for homeless in Switzerland: a prospective study. BMC Infect Dis 2017; 17: 347.

59 Aldridge RW, Hayward AC, Hemming S, et al. Effectiveness of peer educators on the uptake of mobile X-ray tuberculosis screening at homeless hostels: a cluster randomised controlled trial. BMJ Open 2015; 5: e008050.

60 Perlman DC, Friedmann P, Horn L, et al. Impact of monetary incentives on adherence to 
referral for screening chest x-rays after syringe exchange-based tuberculin skin testing. $J$ Urban Health 2003; 80: 428-37.

61 Pilote L, Tulsky JP, Zolopa AR, Hahn JA, Schecter GF, Moss AR. Tuberculosis prophylaxis in the homeless. A trial to improve adherence to referral. Arch Intern Med 1996; 156: 161-5. Lau EA, Ferson MJ. Surveillance for tuberculosis among residents of hostels for homeless men. Aust N Z J Public Health 1997; 21: 447-50.

63 Pande T, Cohen C, Pai M, Ahmad Khan F. Computer-aided detection of pulmonary tuberculosis on digital chest radiographs: a systematic review. Int J Tuberc Lung Dis 2016; 20: 1226-30.

64 Walker TM, Cruz ALG, Peto TE, Smith EG, Esmail H, Crook DW. Tuberculosis is changing. Lancet Infect Dis 2017; 17: 359-61.

65 Walker TM, Ip CLC, Harrell RH, et al. Whole-genome sequencing to delineate Mycobacterium tuberculosis outbreaks: a retrospective observational study. Lancet Infect Dis 2013; 13: 137-46.

66 Marais BJ, Walker TM, Cirillo DM, et al. Aiming for zero tuberculosis transmission in lowburden countries. Lancet Respir Med 2017; published online Oct 12. DOI:10.1016/S22132600(17)30382-X.

67 de Vries SG, Cremers AL, Heuvelings CC, et al. Barriers and facilitators to the uptake of tuberculosis diagnostic and treatment services by hard-to-reach populations in countries of low and medium tuberculosis incidence: a systematic review of qualitative literature. Lancet Infect Dis 2017; 17: e128-43.

68 National Instititute for Clinical Excellence Guidance and Guidelines. Tuberculosis. 2016. https://www.nice.org.uk/guidance/ng33\# (accessed Sept 5, 2017).

69 Getahun H, Matteelli A, Abubakar I, et al. Management of latent Mycobacterium tuberculosis infection: WHO guidelines for low tuberculosis burden countries. Eur Respir J 2015; 46: $1563-76$.

70 Sewell J, Capocci S, Johnson J, et al. Expanded blood borne virus testing in a tuberculosis clinic. A cost and yield analysis. J Infect 2015; 70: 317-23.

71 Diez E, Claveria J, Serra T, et al. Evaluation of a social health intervention among homeless tuberculosis patients. Tuber Lung Dis 1996; 77: 420-4.

72 LoBue PA, Cass R, Lobo D, Moser K, Catanzaro A. Development of housing programs to aid in the treatment of tuberculosis in homeless individuals: a pilot study. Chest 1999; 115: 218 23.

73 Kim S, Crittenden K. Treatment completion among TB patients returned to the community from a large urban jail. J Community Health 2007; 32: 135-47.

74 Juan G, Lloret T, Perez C, et al. Directly observed treatment for tuberculosis in pharmacies compared with self-administered therapy in Spain. Int J Tuberc Lung Dis 2006; 10: 215-21. 
75 Ricks PM, Hershow RC, Rahimian A, et al. A randomized trial comparing standard outcomes in two treatment models for substance users with tuberculosis. Int J Tuberc Lung Dis 2015; 19: $326-32$.

Bock NN, Sales R, Rogers T, Devoe B. NOTES FROM THE FIELD A spoonful of sugar . . : improving adherence to tuberculosis treatment using financial incentives. 2001; 5: 96-8. Story A, Garfein RS, Hayward A, et al. Monitoring Therapy Adherence of Tuberculosis Patients by using Video-Enabled Electronic Devices. Emerg Infect Dis 2016; 22: 538-40. Garfein RS, Collins K, Muñoz F, et al. Feasibility of tuberculosis treatment monitoring by video directly observed therapy: a binational pilot study. Int J Tuberc Lung Dis 2015; 19: $1057-64$.

79 Sinkou H, Hurevich H, Rusovich V, et al. Video-observed treatment for tuberculosis patients in Belarus: findings from the first programmatic experience. Eur Respir J 2017; 49. http://www.ncbi.nlm.nih.gov/pubmed/28331042 (accessed Oct 10, 2017). Story A, Aldridge R, Smith C, et al. S29 A randomised controlled trial comparing smartphone enabled remote video observation with direct observation of treatment for tuberculosis. In: TB: from screening to compliance. BMJ Publishing Group Ltd and British Thoracic Society, 2017: A21.1-A21.

81 Liu Q, Abba K, Alejandria MM, Sinclair D, Balanag VM, Lansang MAD. Reminder systems to improve patient adherence to tuberculosis clinic appointments for diagnosis and treatment. Cochrane database Syst Rev 2014; : CD006594.

82 World Health Organization. Adherence to Long-Term Therapies - Evidence for Action: Section III - Disease-Specific Reviews: Chapter XV - Tuberculosis. http://apps.who.int/medicinedocs/en/d/Js4883e/8.9.1.html (accessed Dec 30, 2017). Story A, Aldridge RW, Abubakar I, et al. Active case finding for pulmonary tuberculosis using mobile digital chest radiography: an observational study. Int J Tuberc Lung Dis 2012; 16: $1461-7$.

84 Kimerling ME, Shakes CF, Carlisle R, Lok KH, Benjamin WH, Dunlap NE. Spot sputum screening: evaluation of an intervention in two homeless shelters. Int J Tuberc Lung Dis 1999; 3: 613-9.

85 McAdam JM, Brickner PW, Scharer LL, Crocco JA, Duff AE. The spectrum of tuberculosis in a New York City men's shelter clinic (1982-1988). Chest 1990; 97: 798-805.

86 Saunders DL, Olive DM, Wallace SB, Lacy D, Leyba R, Kendig NE. Tuberculosis screening in the federal prison system: an opportunity to treat and prevent tuberculosis in foreign-born populations. Public Health Rep 2001; 116: 210-8.

87 Solsona J, Cayla JA, Nadal J, et al. Screening for tuberculosis upon admission to shelters and free-meal services. Eur J Epidemiol 2001; 17: 123-8.

88 Bellin E, Fletcher D, Safyer S. Abnormal chest x-rays in intravenous drug users: implications 
for tuberculosis screening programs. Am J Public Health 1993; 83: 698-700.

89 Badiaga S, Richet H, Azas P, et al. Contribution of a shelter-based survey for screening respiratory diseases in the homeless. Eur J Public Health 2009; 19: 157-60.

90 Barry MA, Wall C, Shirley L, et al. Tuberculosis screening in Boston's homeless shelters. Public Health Rep 1986; 101: 487-94.

91 Brewer TF, Heymann SJ, Krumplitsch SM, Wilson ME, Colditz GA, Fineberg H V. Strategies to decrease tuberculosis in us homeless populations: a computer simulation model. JAMA 2001; 286: 834-42. 